ISSN 2075-163X

www.mdpi.com/journal/minerals

Article

\title{
Calcification and Diagenesis of Bacterial Colonies
}

\section{Ninon Robin ${ }^{1}$, Sylvain Bernard ${ }^{2, *}$, Jennyfer Miot ${ }^{2}$, Marie-Madeleine Blanc-Valleron ${ }^{1}$, Sylvain Charbonnier ${ }^{1}$ and Gilles Petit ${ }^{1}$}

1 CR2P, Centre de Recherche sur la Paléobiodiversité et les Paléoenvironnements, UMR 7207, CNRS, MNHN, UPMC Univ. Paris 06, Paris 75005, France;

E-Mails: nrobin@edu.mnhn.fr (N.R.); valleron@mnhn.fr (M.-M.B.-V.); scharbonnier@mnhn.fr (S.C.); gilles.petit@upmc.fr (G.P.)

2 IMPMC, Institut de Minéralogie, de Physique des Matériaux et de Cosmochimie, UMR 7590, Sorbonne Universités, CNRS, MNHN, UPMC Univ. Paris 06, IRD, Paris 75005, France;

E-Mail: jmiot@mnhn.fr

* Author to whom correspondence should be addressed; E-Mail: sbernard@mnhn.fr;

Tel.: +33-1-4079-3532; Fax: +33-1-4079-5772.

Academic Editor: Caroline Peacock

Received: 15 May 2015 / Accepted: 15 July 2015 / Published: 22 July 2015

\begin{abstract}
Evidencing ancient interspecific associations in the fossil record may be challenging, particularly when bacterial organisms have most likely been degraded during diagenesis. Yet, documenting ancient interspecific associations may provide valuable insights into paleoenvironmental conditions and paleocommunities. Here, we report the multiscale characterization of contemporary and fossilized calcifying bacterial colonies found on contemporary shrimps from Mexico (La Paz Bay) and on 160-Ma old fossilized decapods (shrimps) from the Lagerstätte of La Voulte-sur-Rhône (France), respectively. We document the fine scale morphology, the inorganic composition and the organic signatures of both the contemporary and fossilized structures formed by these bacterial colonies using a combination of electron microscopies and synchrotron-based scanning transmission X-ray microscopy. In addition to discussing the mechanisms of carbonate precipitation by such bacterial colonies, the present study illustrates the degradation of bacterial remains occurring during diagenesis.
\end{abstract}

Keywords: biomineralization; fossilization; biosignatures; epibiosis; diagenesis 


\section{Introduction}

Epibiosis, the association between two species in which one (the epibiont) spends a portion of its life attached to the surface of the second one (the basibiont) [1], has likely involved a broad diversity of taxa over geological time as evidenced by a number of studies having reported fossilized symbiotic organisms [2-12]. Yet, identifying such ancient interspecific associations in the fossil record may be challenging in the case of epibiotic micro-organisms, notably because of their poor resistance to diagenetic degradation. For instance, only some rare fossilized examples of epibiosis have been reported within Precambrian rocks such as the Gunflint Formation [13]. Nevertheless, documenting such interspecific associations over geological timescales may provide new insights into processes and mechanisms of evolution as well as into paleoenvironments and paleocommunities.

Although a number of studies have reported the (partial) preservation of resistant organic macromolecules such as sporopollenin or chitin [14-17], identification of remains of micro-organisms within fossilized structures remains complicated as microbial-like morphologies may also be produced through abiotic processes [18,19]. Adding to controversies, bio-alteration and burial-induced processes inevitably alter the original biochemical signatures of organic molecules [20,21]. As a result, the general paleobiological perception has long been that burial and diagenetic processes are detrimental to the preservation of biosignatures. Yet, metamorphic rocks may retain, to some extent, morphologically and geochemically recognizable traces of life [14,22-25].

Biomineralized micro-organisms appear more resistant to diagenesis than non-biomineralized ones [26-29]. For instance, biologically mediated calcification of bacteria, which is involved in the formation of stromatolites or microbialites [30-32], has been described as a key process contributing to their fossilization $[27,29,30,33]$. The propensity of biogenic organo-mineral assemblages to overcome degradation during diagenesis might be dependent upon a number of parameters, including the paleoenvironmental and diagenetic conditions. Undoubtedly, the original nature of the minerals, their mode of formation (biomineralization $v s$. abiotic precipitation) as well as their structural and textural relationships with the organic components play a crucial role. Comparative study of contemporary and fossilized biomineralized microbial structures may allow to better constrain the respective influence of all these parameters on the diagenetic evolution of biogenic organo-mineral assemblages.

Here, we report the multiscale characterization of organo-mineral structures observed on the carapace of contemporary decapods (shrimps) from La Paz Bay (Mexico) as well as on fossilized counterparts from the Callovian Lagerstätte of La Voulte-sur-Rhône, France [34]. Of note, a number of studies have reported the presence of epibiotic micro-organisms, such as diatoms, cliliates and bacteria, on extant decapods [10,35-38]. Here, the use of advanced analytical techniques including X-ray diffraction (XRD), scanning and transmission electron microscopies (SEM \& TEM) and scanning transmission X-ray microscopy (STXM) allow documenting submicrometer-scale chemical and structural features within the contemporary specimens, identifying these structures as epibiotic calcifying bacterial colonies and discussing the mechanisms of carbonate precipitation by these micro-organisms. In addition, the comparison with fossilized counterparts from La Voulte-sur-Rhone allows discussing the morphological and geochemical evolution of such objects during burial and diagenesis. 


\section{Material and Methods}

\subsection{Investigated Specimens}

The investigated contemporary calcifying bacterial colonies have been collected on the cuticle of extant decapods (shrimps) belonging to the species Farfantepenaeus brevirostris (Kingsley, 1878, MNHN.IU. Na8524) (Figure 1). These shrimps and their epibiotic bacterial colonies have been caught alive in the La Paz Bay (Mexico) and preserved, since their capture, in $70 \%$ alcohol in order to maintain their structural and chemical integrity. Epibiotic organo-mineral structures have been detected on the whole carapace (pleon, carapace and telson) of most of the 20 sampled specimens, covering up to $10 \%$ of the whole animal (Figure 1) [11].

The investigated fossilized counterparts have been observed on the carapace of two fossil decapods (Archeosolenocera straeleni Carriol and Riou, 1991, UMPC-150 and Aeger brevirostris Van Straelen, 1923, MNHN.F.R61863) morphologically preserved in three dimensions within carbonate concretions from the Callovian Lagerstätte of La Voulte-sur-Rhône (France) (Figure 1) [34]. Although a smaller number of fossilized epibiotic structures have been observed on these fossilized shrimps compared to their modern counterparts, they cover about $5 \%$ of their surface (Figure 1). Fossilization of these shrimps occurred rapidly [39], through a quite common mineralogical diagenetic sequence (apatite, calcite, gypsum, pyrite, chalcopyrite and galena), indicating quite low diagenetic pressure and temperature conditions.

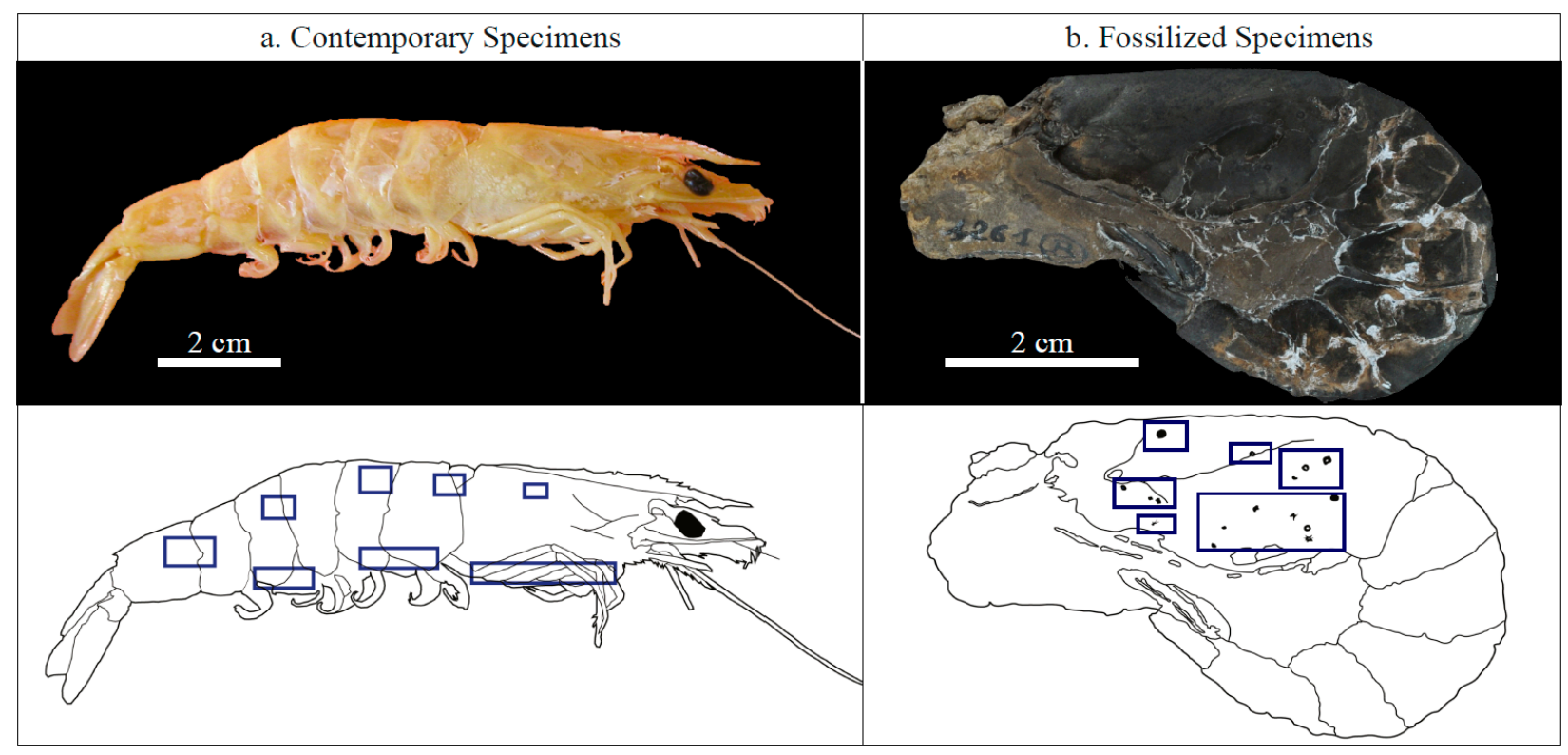

Figure 1. Images of the decapod materials hosting the investigated contemporary and fossilized epibiotic calcifying bacterial colonies. (a) Photograph and schematic representation of a contemporary specimen of Farfantepenaeus brevirostris (Kingsley, 1878, MNHN.IU. Na8524), from La Paz Bay, Mexico. (b) Photograph and schematic representation of a fossilized specimen of Aeger brevirostris Van Straelen, 1923 (MNHN.F.R61863) from the Callovian of La Voulte-sur Rhône. Blue squares indicate the location of epibiotic calcifying bacterial colonies. 


\subsection{X-Ray Diffraction}

The mineralogy of the investigated recent epibionts has been determined by X-ray diffraction (XRD) using the Bruker D2 PHASER operating at the MNHN (Paris, France) with a Lynxeye detector (opening: $5.821^{\circ}$ 2Theta) and a Ni-filtered $\mathrm{Cu} \mathrm{K \alpha}$ radiation $(30 \mathrm{kV}, 10 \mathrm{~mA})$ with a $0.02^{\circ}$ step width. Fresh cuticles and cuticles covered by epibionts have been crushed in an agate mortar and mounted as thin smears on zero-background Si plates.

\subsection{Scanning Electron Microscopy (SEM)}

Both extant and fossil specimens have been characterized using the Zeiss Supra 55 Scanning Electron Microscope (SEM) operating at the IMPMC (Paris, France). Secondary electron images have been collected at $5 \mathrm{kV}$ accelerating voltage and a working distance of $2.5 \mathrm{~mm}$. Elemental compositions have been semi-quantitatively determined by energy dispersive X-ray spectrometry (EDXS) using a Bruker EDS QUANTAX detector (Bruker Corporation, Houston, TX, USA) and the software ESPRIT at $15 \mathrm{kV}$ accelerating voltage and a working distance of $7.5 \mathrm{~mm}$.

\subsection{Focused Ion Beam (FIB) Milling}

Focused ion beam (FIB) milling has been performed at low Ga-ion currents using the FEI STRATA DB 235 FIB system operating at the IEMN (Lille, France) to prepare electron and soft X-ray transparent $\sim 15 \mu \mathrm{m} \times 5 \mu \mathrm{m} \times 80 \mathrm{~nm}$ cross-sections [40]. This extraction procedure maintains textural integrity, even in the case of loosely consolidated materials [41,42], and prevents shrinkage and deformation of microscale to nanoscale pores, even in the case of highly sensitive materials $[43,44]$. Milling at low Ga-ion currents has allowed preventing common artifacts like local gallium implantation, mixing of components, creation of vacancies or interstitials, creation of amorphous layers, local composition changes or redeposition of the sputtered material on the sample surface $[41,42,45-47]$. In addition, milling at low Ga-ion currents prevents significant changes in the speciation of complex carbon-based polymer [15,48].

\subsection{Transmission Electron Microscopy (TEM)}

Transmission electron microscopy (TEM) analyses of FIB section were performed with a $200 \mathrm{kV}$ JEOL 2100 field emission gun (FEG) microscope (JEOL Ltd, Tokyo, Japan) operating at the IMPMC (Paris, France). Scanning transmission electron microscopy imaging was performed in high-angle annular dark field (HAADF) mode.

\subsection{Scanning Transmission X-Ray Microscopy (STXM) and X-Ray Absorption Near Edge Structure (XANES) Spectroscopy}

X-ray absorption near edge structure (XANES) measurements of the present study were done using the Scanning transmission X-ray microscope (STXM) located on beamline 5.3.2.2 (STXM Polymer beamline) at the Advanced Light Source (ALS) [49]. Beamline 5.3.2.2. (ALS) uses soft X-rays $(250-800 \mathrm{eV})$ generated via a bending magnet while the electron current in the storage ring is held 
constant in top-off mode at $500 \mathrm{~mA}$ at a storage ring energy of $1.9 \mathrm{GeV}$. The microscope chamber was evacuated to 100 mTorr after sample insertion and back-filled with He. Energy calibration was accomplished using the well-resolved 3p Rydberg peak at $294.96 \mathrm{eV}$ of gaseous $\mathrm{CO}_{2}$ for the C K-edge. Alignment of images of stacks and extraction of XANES spectra were done using the aXis2000 software (Ver 2.1n). Spectral peak positions, intensities and widths were determined using the Athena software package [50]. The XANES spectra shown in the present contribution correspond to homogeneous organic-rich areas of several hundreds of nanometers. Although radiation damage per unit of analytical information has been shown to be typically 100-1000 times lower in STXM-based XANES spectroscopy than in TEM-based electron energy loss spectroscopy (EELS) [51-54], the C-XANES data shown here have been collected following the procedures for X-ray microscopy studies of radiation sensitive samples [55].

\section{Results}

\subsection{Contemporary Epibiotic Organo-Mineral Structures}

\subsubsection{Morphology}

The investigated contemporary epibiotic organo-mineral structures appear as rigid, flat and transparent structures fixed on the shrimp cuticle. They exhibit discoid, lobed, or rhizoid morphologies (Figure 2). They measure $50-800 \mu \mathrm{m}$ in diameter and may be either found isolated or adjoined (Figure 2). The surface of these epibiotic structures is either quite smooth or highly ornamented (Figure 3). Some of them exhibit a smooth rosette at their center and highly ornamented areas in the periphery (Figure 3). High magnification observations reveal that these ornamentations consist in the agglomeration of globular structures measuring $\sim 1.5 \mu \mathrm{m}$ in diameter (Figure 3). Observations of transversal sections of these globular structures reveal their stick-like morphologies in three-dimensions that outcrop at the surface of the bacterial colony in the form of globules (Figure 3). The surface of these sticks appears covered by layers of a smooth and lumpy film resembling a microbial mat-like structure (Figure 3). Both the size and morphology of these stick-like forms evoke bacteria. In a similar perspective, the sizes and morphologies of the discoid, lobed and rhizoid structures formed by the assemblage of these sticks are consistent with bacterial colonies at different stages of growth [56,57]. Observations of cross-sections reveal that these epibiotic structures have a mean thickness of about $15 \mu \mathrm{m}$ with a thicker central part (Figure 4). 

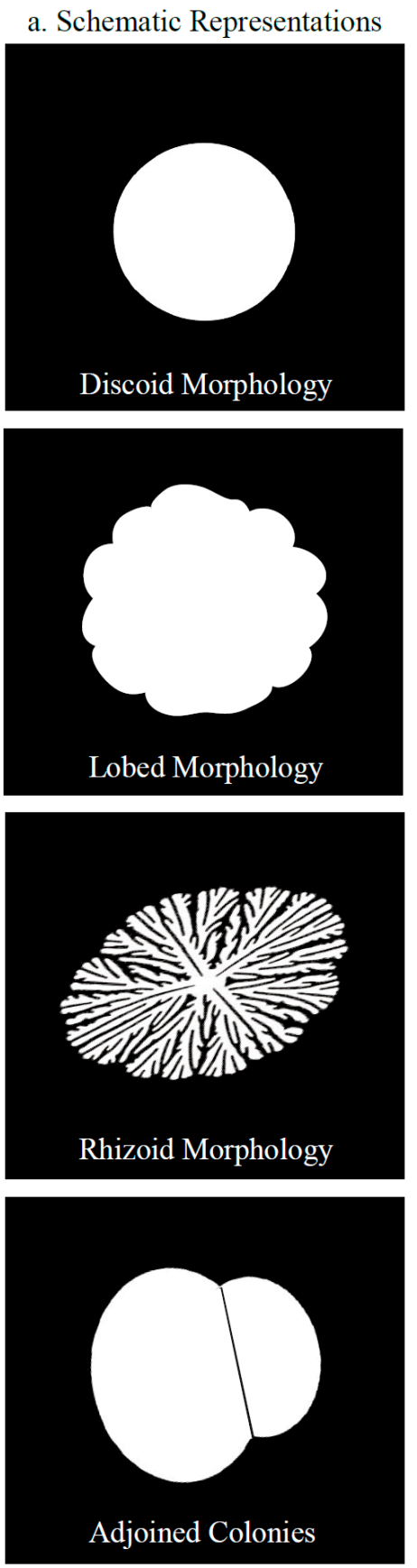

b. Contemporary Specimens
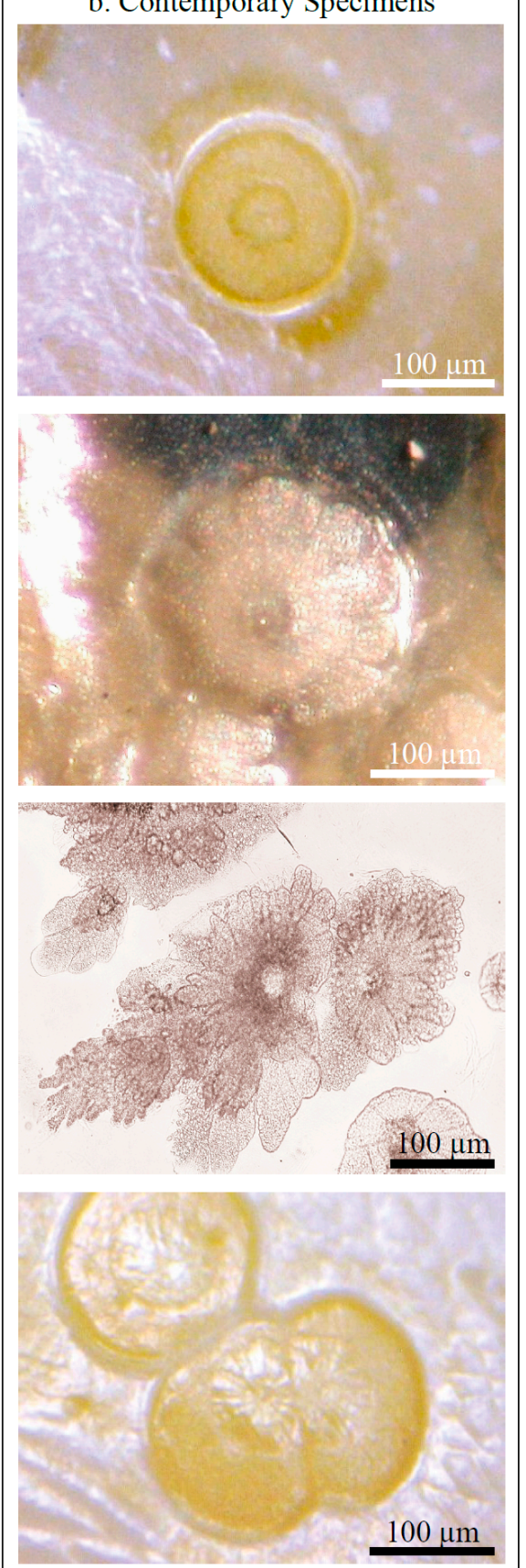

c. Fossilized Specimens
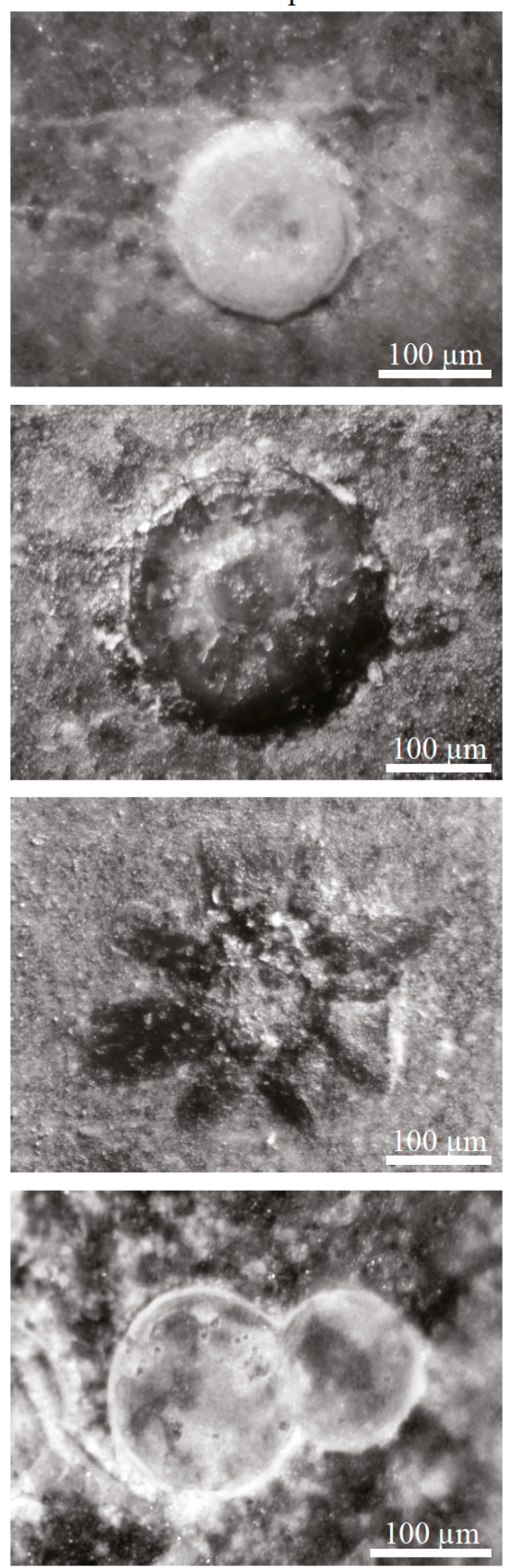

Figure 2. Morphologies of the investigated specimens of epibiotic calcifying bacterial colonies: schematic representations (a), photomicrographs of contemporary (b) and fossilized (c) specimens illustrating the discoid, the lobed and the rhizoid radial morphologies and showing adjoined colonies. 


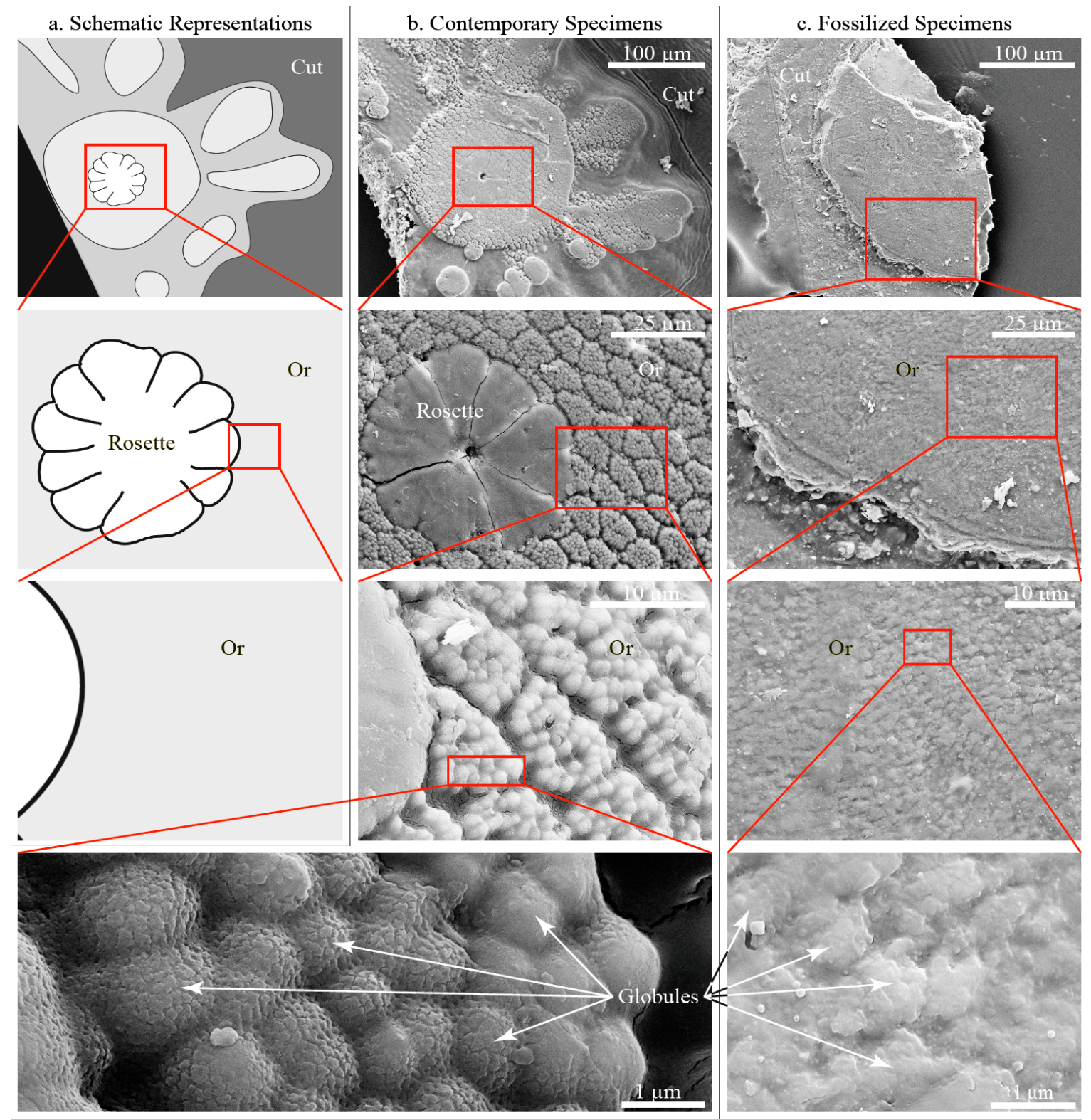

d. 3d Observations of Contemporary Specimens exhibiting Stick-like Structures

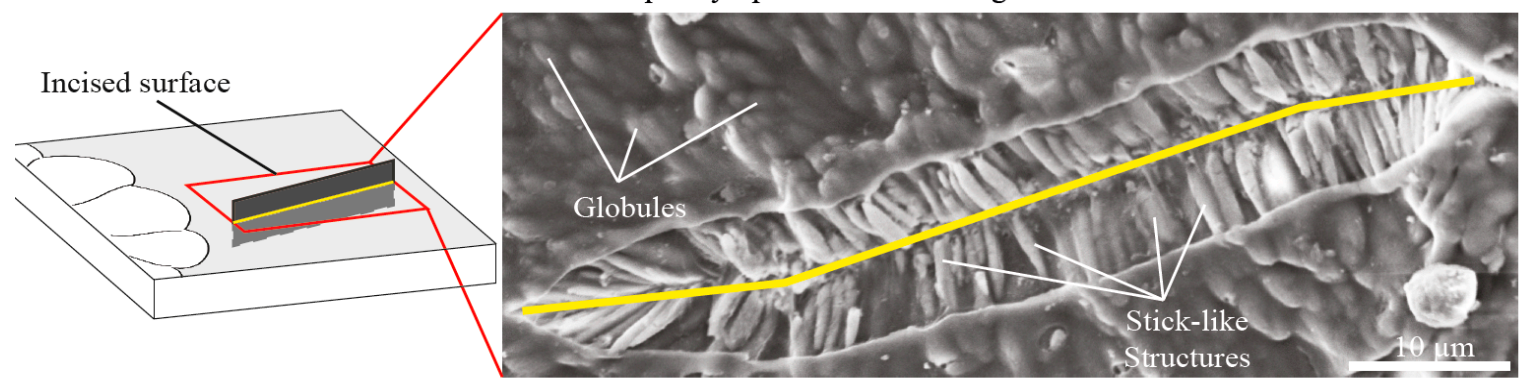

Figure 3. Fine-scale morphologies of the investigated contemporary and fossilized epibiotic calcifying bacterial colonies. (a) schematic representations, (b) SEM images (secondary electrons) of contemporary specimens and (c) SEM images (secondary electrons) of fossilized specimens at different magnifications (Cut $=$ decapod cuticle, Or $=$ ornamentations). (d) Schematic representation and SEM image (secondary electrons) of an incised surface of a contemporary epibiotic bacterial colony exhibiting stick-like structures outcropping at the surface in the form of globules. 


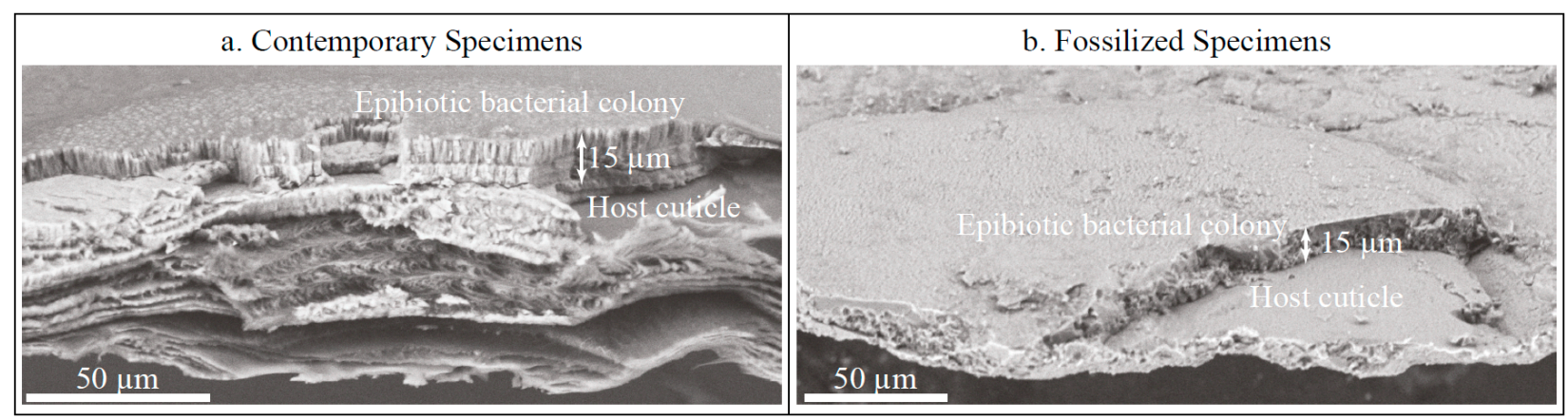

Figure 4. Thicknesses of the investigated contemporary and fossilized epibiotic calcifying bacterial colonies. (a) SEM image (secondary electrons) of a section of a contemporary specimen. (b) SEM image (secondary electrons) of a section of a fossilized specimen.

\subsubsection{Composition}

The iridescence of the surface of the investigated contemporary epibiotic organo-mineral structures when illuminated with polarized light indicates a crystalline nature (Figure 5). XRD patterns of crushed samples reveal that these objects are made of calcite while epibiont-free cuticles display a typical alpha-chitinous XRD pattern (Figure 5). EDXS analyses confirm the calcitic composition of the investigated epibiotic structures and evidence low concentrations of iron and magnesium. Significant amounts of carbon and nitrogen are systematically observed in association with this low Mg-calcite (Figure 5).

TEM and STXM images of FIB foils reveal an alternation of mineralized stick-like structures with non-mineralized filaments of a few hundreds of nanometers (Figure 6). The C-XANES spectrum of the stick-like structures exhibits a main peak at $290.3 \mathrm{eV}$ attributed to $1 \mathrm{~s} \rightarrow \pi^{*}$ electronic transitions of carbon in carbonate groups $\left(\mathrm{CO}_{3}\right)$ (Figure 6) [58] and a second absorption peak at $288.6 \mathrm{eV}$, generally attributed to carboxylic functional groups [59]. Such C-XANES spectra have been previously attributed to carbonates closely associated with organics [60-62]. These stick-like low Mg-carbonates closely associated with organics are consistent with calcified microbial remains [63-65].

The non-mineralized filaments located in between the carbonate stick-like structures exhibit a C-XANES spectrum with a main absorption peak at $288.2 \mathrm{eV}$, attributed to $1 \mathrm{~s} \rightarrow \pi^{*}$ electronic transitions of carbon in amide groups, a peak at $285.2 \mathrm{eV}$, attributed to electronic transitions of carbon in aromatic or olefinic carbon groups, and two additional peaks at 287.3 and $289.4 \mathrm{eV}$, attributed to $1 s \rightarrow \pi^{*}$ or $1 s \rightarrow 3 \mathrm{p} / \sigma^{*}$ electronic transitions of hydroxylated- or ether-linked carbon species, respectively (Figure 6) [59]. The carbon functional groups responsible for the presence of these peaks may enter the composition of proteins (aromatic and amide groups), lipids (aliphatic groups) and polysaccharides (carboxylic groups). The spectrum of these filaments is thus typical of bacterial organic matter [59-62,66]. This bacterial origin is confirmed by XANES analyses at the N K-edge. The N-XANES spectra of these organics exhibit two sharp peaks at 399.8 and $401.2 \mathrm{eV}$, attributed to electronic transitions of nitrile $(\mathrm{C} \equiv \mathrm{N})$ and amidyl groups $\left(\mathrm{CO}-\mathrm{NH}_{x}\right)$, respectively, and a shoulder at $399 \mathrm{eV}$, likely corresponding to amine groups (Figure 6) [67-69]. 


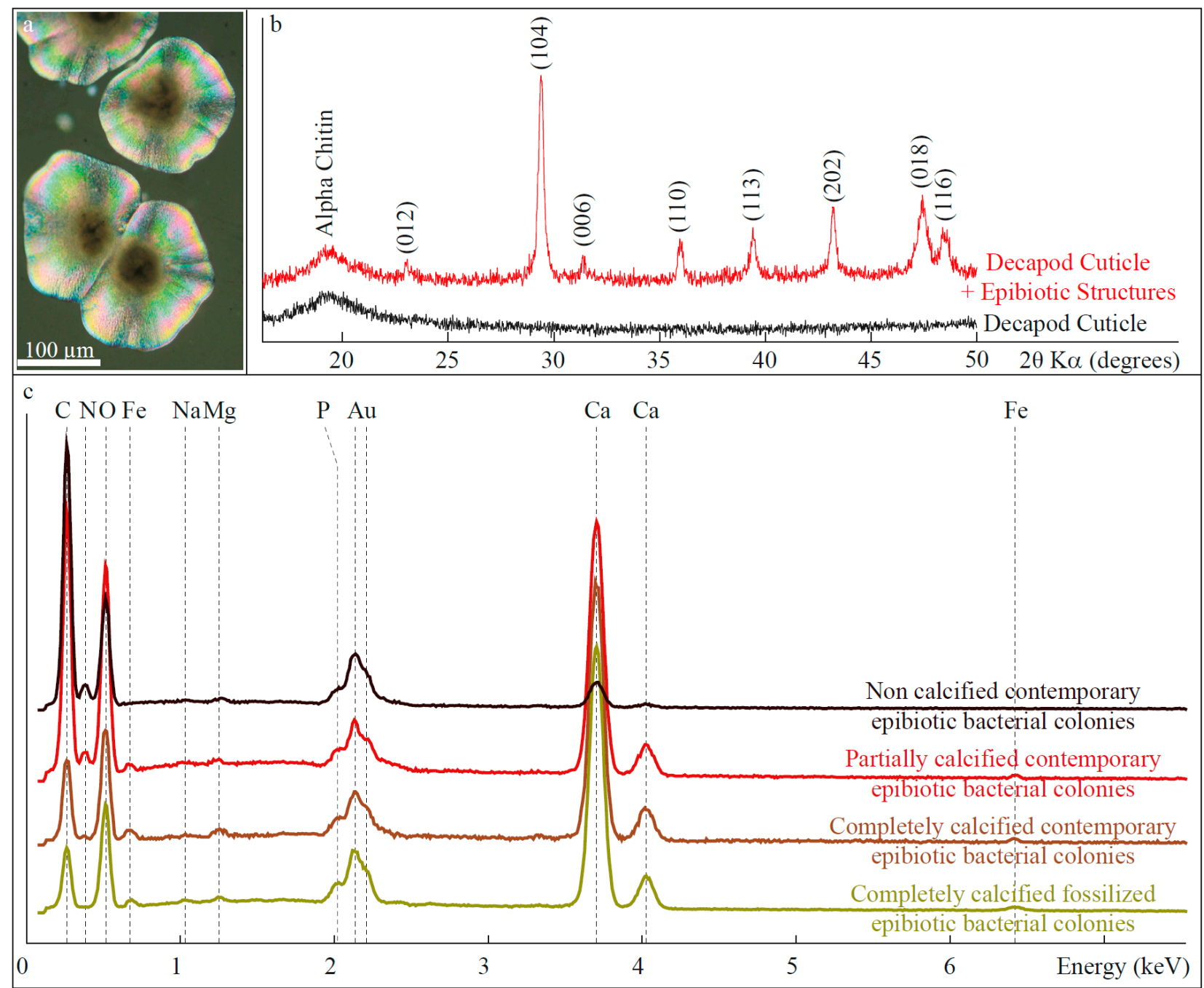

Figure 5. Inorganic composition of the investigated contemporary and fossilized epibiotic calcifying bacterial colonies. (a) Photomicrograph of iridescent contemporary specimens of epibiotic calcifying bacterial colonies. (b) XRD patterns of contemporary epibiotic calcifying bacterial colonies and of a piece of the host decapod cuticle free of epibiotic bacterial colony. While the host cuticle exhibit an alpha-chitinous signal, contemporary epibiotic calcifying bacterial colonies exhibit peaks consistent with calcite planes. (c) EDXS signals of more or less mineralized contemporary and fossilized epibiotic calcifying bacterial colonies. All signals are consistent with Ca carbonates containing small amounts of $\mathrm{Fe}$ and $\mathrm{Mg}$. Note that the organics can be identified from the presence of $\mathrm{C}$ and $\mathrm{N}$ in partially mineralized contemporary and fossilized epibiotic calcifying bacterial colonies. 


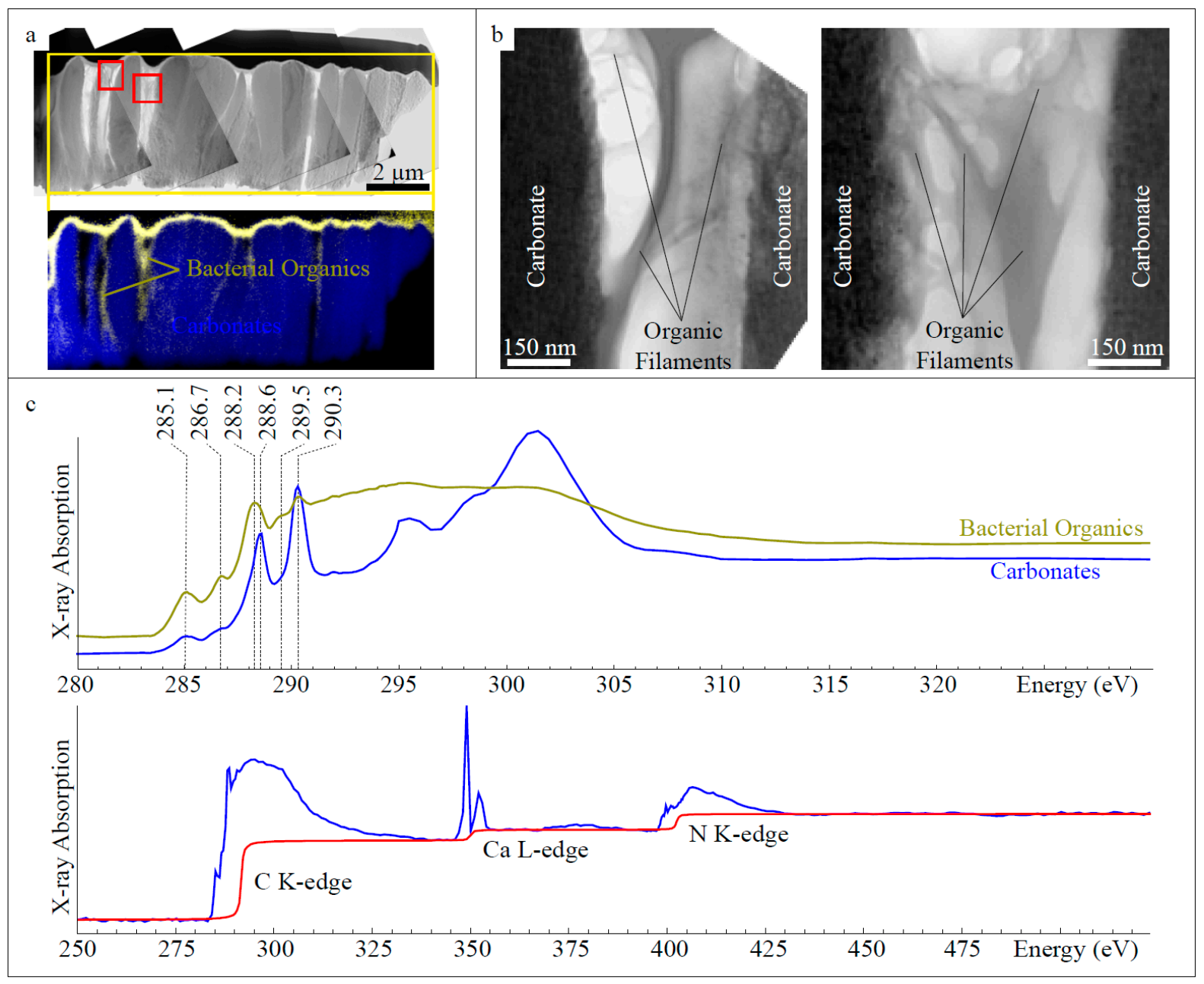

Figure 6. Organic composition of the investigated contemporary and fossilized epibiotic calcifying bacterial colonies. (a) Top: TEM image of an ultrathin FIB foil of sample extracted from a contemporary epibiotic calcifying bacterial colony (red squares indicate the location of TEM images shown in (b)). Bottom: STXM compositional map of the ultrathin foil showing the spatial distribution of carbonates (blue) and organics (yellow). (b) TEM images of areas of the ultrathin FIB foil shown in (a). Organic filaments appear in dark. (c) Top: C-XANES spectra of organics and carbonates composing the ultrathin FIB foil shown in (a) (peaks at 285.1, 286.7, 288.2, 288.6, 289.5 and $290.3 \mathrm{eV}$ are attributed to electronic transitions of carbon involved in aromatic of olefinic, phenolic, amidyl, carboxylic, hydroxylated and carbonate groups, respectively). Bottom: XANES spectrum of the epibiotic bacterial organic matter collected over the carbon and nitrogen absorption edge showing its $\mathrm{N}$-rich nature (atomic $\mathrm{N} / \mathrm{C}=0.2$ ).

\subsection{Fossilized Epibiotic Structures}

The investigated fossilized epibiotic structures appear as rigid and flat structures fixed on the cuticle of fossilized decapods (shrimps) from the Callovian Lagerstätte of La Voulte-sur-Rhône (France). Similarly to the contemporary epibiotic structures investigated in the present study, these fossilized structures exhibit discoid, lobed, or rhizoid morphologies (Figure 2). They measure 50-500 $\mu \mathrm{m}$ in diameter (with a few of displaying a diameter up to $600 \mu \mathrm{m}$ ). Most of them are isolated but some may 
be found contiguous to each other (Figure 2). Although the surface of these epibiotic structures appears structure-free by optical microscopy (Figure 3), high magnification SEM observations reveal fine-scale ornamentations consisting in the agglomeration of globular structures of 1-2 $\mu \mathrm{m}$ in diameter (Figure 3). Observations of cross-sections reveal a total thickness of $\sim 15 \mu \mathrm{m}$ (Figure 4). As shown by EDXS analyses, the investigated epibiotic structures have a calcitic composition with low concentrations of iron and magnesium (Figure 5). No organic matter has been detected in association with these fossilized calcified epibiotic structures using either EDXS or XANES spectroscopy.

\section{Discussion}

Here, we report the multiscale characterization of contemporary organo-mineral epibiotic structures that we identify as bacterial colonies based on their morphological and geochemical signatures. As the investigated contemporary and fossilized epibiotic structures share numerous similarities down to the submicrometer scale, the fossilized epibiotic structures are interpreted as fossilized calcifying epibiotic bacterial colonies. Of note, a palaeoecological complementary study has revealed the probable ectoparasitic habit of these bacterial colonies [11]. This symbiosis close to parasitism has thus existed for at least 160 myr. Here, we first discuss the possible biomineralization processes leading to the precipitation of low $\mathrm{Mg}$ calcite by these bacterial colonies. Then, based on the comparison between the investigated contemporary and fossilized specimens, we discuss the impact of diagenetic processes on the preservation/degradation of the biosignatures of such calcifying bacterial colonies.

\subsection{Biomineralization of Calcified Epibiotic Bacterial Colonies}

The highly structured sub-micrometric association of calcite with organic molecules dominated by proteic moieties exhibited by the contemporary bacterial colonies suggests a formation resulting from biomineralization processes [60,70]. Two main pathways of bacteria-induced/controlled carbonate precipitation have been reported in modern environments and laboratory cultures [64,71-74].

(1) The formation of miscellaneous crystalline carbonates (e.g., aragonite, $\mathrm{Mg}$-rich or $\mathrm{Mg}$-low calcite, dolomite) may result from extracellular precipitation [72,75-78]. In this case, negatively charged groups exposed at the surface of the cell and/or of exopolymeric substances (EPS) act as mineral nucleation sites for carbonate precipitation, so that organic matter is intimately associated with carbonate minerals. This process is dependent upon the microenvironmental chemical conditions $\left(\mathrm{Ca}^{2+}\right.$ and dissolved inorganic carbon concentrations) that can be controlled by biological activity from different metabolisms such as sulfate-reduction, oxygenic or anoxygenic photosynthesis [63,79-82].

(2) Alternatively, biomineralization may occur intracellularly. Intracellular carbonate precipitation, as recently evidenced for multiple strains of cyanobacteria $[73,83]$, may lead to the accumulation of calcium carbonates within bacterial cells. Whereas gas vesicles function as flotation devices in planktonic prokaryotes [84], the precipitation of intracellular carbonates has been proposed to potentially serve as ballasts [73], thus facilitating benthic (or epibiotic) modes of life. Additionally, such carbonate precipitation has been proposed to possibly act as a $\mathrm{pH}$ buffering system [73] that may facilitate carbon concentrating mechanisms and thus improve bacterial colony growth rate.

Here, we evidence the presence of $\sim 1 \mu \mathrm{m}$ wide stick-like carbonate structures exhibiting an absorption peak at $288.6 \mathrm{eV}$ in their C-XANES spectra. This peak could be attributed to the presence 
of EPS [85]. These minerals may thus result from extracellular precipitation of amorphous carbonates that may preferentially occur onto EPS molecules. The vertical orientation of the carbonate sticks may be related to that of the calcifying bacteria anchored at the surface of the decapod cuticle, as it has already been observed for filamentous cyanobacteria in stromatolites [74]. In these formations, heterotrophic degradation of cyanobacterial EPS is generally invoked to explain the progressive replacement of amorphous carbonates by calcite, leading to a porous microstructure composed of bacterial filaments and carbonates [74].

Alternatively, as the carbonate stick-like structures described here exhibit sizes and morphologies comparable to cyanobacteria, they might be interpreted as resulting from intracellular bacterial calcification. In this scenario, the organic filaments observed around these stick-like carbonates might constitute remains of bacterial membranes. The precipitation of carbonates within the bacterial cells may have first served to facilitate the long-term fixation of bacterial colonies on the decapod cuticles. Although these carbonates might have first been small amorphous spheres within the bacteria cells, they may have merged and evolved towards crystalline calcite after the death of bacteria [78].

\subsection{Fossilization of Calcifying Bacterial Colonies}

Preservation of chemical and/or morphological bacterial signatures in fossils is promoted by several factors in addition to limited heterotrophic processes (i.e., biodegradation of organic matter) [33]. For instance, carbonate and phosphate biomineralization has been shown to efficiently preserve molecular signatures of biogenic organic molecules [28,29]. In addition, the location of mineral precipitation with respect to the bacterial ultrastructures has also been shown to influence the extent of biosignature preservation. For instance, periplasm encrustation has been described as favoring bacterial morphology preservation [26,61,86]. Specific crystallographic orientation (perpendicular to cell walls) of crystalline phases precipitated within bacterial periplasm [61,86,87], at the cell surface or in association with cyanobacterial sheaths [32] may also promote the preservation of specific biosignatures upon fossilization and diagenetic processes. Last, trapping of organics within minerals upon diagenesis and even metamorphism has been shown to allow, to some extent, the preservation of geochemical biosignatures [14,24,25,29,88].

Here, the morphologies of the fossilized calcifying bacterial colonies appear very similar to the ones of the contemporary colonies, even down to the submicrometer scale. Such fine-scale morphological preservation likely results from the early mineralization of bacterial cells. Yet, no organic carbon has been detected in association with the fossil epibionts using EDXS or XANES spectroscopy. The bacterial organics originally constituting the fossilized calcifying epibiotic bacterial colonies have thus been completely degraded during fossilization and burial processes. Such loss of organic carbon upon fossilization suggests that carbonate biomineralization did occur neither within bacterial cell walls nor at the cell surface. This observation appears in favor of an intracellular process of carbonate biomineralization as it may not promote organic carbon preservation as previously suggested [73]. Thus, the absence of a "bacterial signature" within mineral phases may not always be inconsistent with a bacterial origin and may modify the general perception of a number of specimens that might be worth re-exploring for the search for traces of ancient life in rocks. 


\section{Concluding Remarks}

The multiscale characterization reported here strongly suggests that the investigated contemporary and fossilized epibiotic structures observed on modern and fossilized decapod cuticles can be identified as modern and fossilized calcifying bacterial colonies, respectively. Yet, the exact calcifying process responsible for the formation of these biomineralized structures, either intracellular or extracellular, remains difficult to constrain. The fine-scale morphologies of the investigated fossilized calcifying bacterial colonies appear to have been exceptionally well preserved down to the micrometer scale, likely as the result of the early mineralization of bacterial cells. Yet, the original bacterial organics have been totally degraded during fossilization and burial. Such degradation upon fossilization, despite the rather low pressure and temperature diagenetic conditions experienced by these samples, may be ascribed to particularities of the biomineralization processes (absence of periplasmic or cell surface encrustation).

\section{Acknowledgements}

We gratefully acknowledge support from the ERC (project PaleoNanoLife-PI: F. Robert). Special thanks go to Simona Pestrea and Jean-Paul Saint Martin for their help with optical microscopy and fruitful discussions and special thanks go to David Troadec for the preparation of FIB sections. The SEM facility of the IMPMC is supported by Région Ile de France grant SESAME 2006 NI-07-593/R, INSU-CNRS, INP-CNRS, UPMC-Paris 6, and by the Agence Nationale de la Recherche (ANR) grant No. ANR-07-BLAN-0124-01. Special thanks go to Imene Esteve for her expert support of the SEM at IMPMC. The TEM facility of the IMPMC is supported by Region Ile de France grant SESAME 2000 E 1435. Special thanks go to Jean-Michel Guigner for his expert support of the TEM at IMPMC. STXM-based XANES data were acquired at beamline 5.3.2.2 at the Advanced Light Source (ALS), which is supported by the Director of the Office of Science, Department of Energy, under Contract No. DE-AC02-05CH11231. Special thanks go to David Kilcoyne for his expert support of the STXM at the ALS. Comments from three reviewers have been very helpful in improving the present manuscript.

\section{Author Contributions}

N.R., S.B., J.M., S.C. and G.P. conceived and designed the experiments. S.C. and G.P. provided the samples. N.R., S.B., J.M. and M.M.B.V. performed the experiments. N.R., S.B. and J.M. interpreted the data and wrote the present article.

\section{Conflicts of Interest}

The authors declare no conflict of interest.

\section{References}

1. Fernandez-Leborans, G. Epibiosis in Crustacea: An overview. Crustaceana 2010, 83, 549-640.

2. Brandt, D.S. Epizoans on Flexicalymene (Trilobita) and implications for trilobite paleoecology. J. Paleontol. 1996, 70, 442-449. 
3. Waugh, D.A.; Feldmann, R.M.; Crawford, R.S.; Jakobsen, S.L.; Thomas, K.B. Epibiont preservational and observational bias in fossil marine decapods. J. Paleontol. 2004, 78, 761-767.

4. Galle, A.; Parsley, R.L. Epibiont relationships on hyolithids demonstrated by Ordovician trepostomes (Bryozoa) and Devonian tabulates (Anthozoa). Bull. Geosci. 2005, 80, 125-138.

5. Engel, M.S. An Eocene ectoparasite of bees: The oldest definitive record of phoretic meloid triungulins (Coleoptera: Meloidae; Hymenoptera: Megachilidae). Acta Zool. Cracoviensia 2005, 48, 43-48.

6. Wisshak, M.; Neumann, C. A symbiotic association of a boring polychaete and an echinoid from the Late Cretaceous of Germany. Acta Palaeontol. Pol. 2006, 51, 589-597.

7. Dunlop, J.A.; Kontschán, J.; Zwanzig, M. Fossil mesostigmatid mites (Mesostigmata: Gamasina, Microgyniina, Uropodina), associated with longhorn beetles (Coleoptera: Cerambycidae) in Baltic amber. Naturwissenschaften 2013, 100, 337-344.

8. Petit, G.; Charbonnier, S. Fossil sponge gemmules, epibionts of Carpopenaeus garassinoi $n$. $s p$. (Crustacea, Decapoda) from the Sahel Alma Lagerstätte (Late Cretaceous, Lebanon). Geodiversitas 2012, 34, 359-372.

9. Misaki, A.; Maeda, H.; Kumagae, T.; Ichida, M. Commensal anomiid bivalves on Late Cretaceous heteromorph ammonites from south - west Japan. Palaeontology 2014, 57, 77-95.

10. Robin, N.; Charbonnier, S.; Bartolini, A.; Petit, G. First occurrence of encrusting nubeculariids (Foraminifera) on a mobile host (Crustacea, Decapoda) from the Upper Jurassic Eichstätt Lagerstätte, Germany: A new possible relation of phoresy. Mar. Micropaleontol. 2013, 104, 44-52.

11. Robin, N.; Petit, G.; Charbonnier, S. A newly recognized Mesozoic-Recent interspecific association: Calcifying bacteria on decapod crustaceans. Lethaia 2015, doi:10.1111/let.12120.

12. Siveter, D.J.; Briggs, D.E.; Siveter, D.J.; Sutton, M.D. A 425-Million-Year-Old Silurian Pentastomid Parasitic on Ostracods. Curr. Biol. 2015, 25, 1632-1637.

13. Wacey, D.; McLoughlin, N.; Kilburn, M.R.; Saunders, M.; Cliff, J.B.; Kong, C.; Barley, M.E.; Brasier, M.D. Nanoscale analysis of pyritized microfossils reveals differential heterotrophic consumption in the 1.9-Ga Gunflint chert. Proc. Natl. Acad. Sci. USA 2013, 110, 8020-8024.

14. Bernard, S.; Benzerara, K.; Beyssac, O.; Menguy, N.; Guyot, F.; Brown, G.E.; Goffe, B. Exceptional preservation of fossil plant spores in high-pressure metamorphic rocks. Earth Planet. Sci. Lett. 2007, 262, 257-272.

15. Bernard, S.; Benzerara, K.; Beyssac, O.; Brown, G.E.; Stamm, L.G.; Duringer, P. Ultrastructural and chemical study of modern and fossil sporoderms by Scanning Transmission X-ray Microscopy (STXM). Rev. Palaeobot. Palynol. 2009, 156, 248-261.

16. Ehrlich, H.; Rigby, J.K.; Botting, J.P.; Tsurkan, M.V.; Werner, C.; Schwille, P.; Geisler, T. Discovery of 505-million-year old chitin in the basal demosponge Vauxia gracilenta. Sci. Rep. 2013, 3, 3497.

17. Wysokowski, M.; Zaton, M.; Bazhenov, V.V.; Behm, T.; Ehrlich, A.; Stelling, A.; Hog, M.; Ehrlich, H. Identification of chitin in 200-million-year-old gastropod egg capsules. Paleobiology 2014, 40, 529-540.

18. Garcia-Ruiz, J.M.; Carnerup, A.; Christy, A.G.; Welham, N.J.; Hyde, S.T. Morphology: An ambiguous indicator of biogenicity. Astrobiology 2002, 2, 353-369. 
19. Schopf, J.W.; Kudryavtsev, A.B.; Sugitani, K.; Walter, M.R. Precambrian microbe-like pseudofossils: A promising solution to the problem. Precambrian Res. 2010, 179, 191-205.

20. Vandenbroucke, M.; Largeau, C. Kerogen origin evolution and structure. Org. Geochem. 2007, 38, 719-833.

21. Bernard, S.; Papineau, D. Graphitic carbons and biosignatures. Elements 2014, 10, 435-440.

22. Butterfield, N.J.; Balthasar, U.; Wilson, L.A. Fossil diagenesis in the Burgess Shale. Palaeontology 2007, 50, 537-543.

23. Schiffbauer, J.D.; Yin, L.M.; Bodnar, R.J.; Kaufman, A.J.; Meng, F.W.; Hu, J.; Shen, B.; Yuan, X.L.; Bao, H.M.; Xiao, S.H. Ultrastructural and geochemical characterization of Archean-Paleoproterozoic graphite particles: Implications for recognizing traces of life in highly metamorphosed rocks. Astrobiology 2007, 7, 684-704.

24. Bernard, S.; Benzerara, K.; Beyssac, O.; Brown, G.E., Jr. Multiscale characterization of pyritized plant tissues in blueschist facies metamorphic rocks. Geochim. Cosmochim. Acta 2010, 74, 5054-5068.

25. Galvez, M.E.; Beyssac, O.; Benzerara, K.; Bernard, S.; Menguy, N.; Cox, S.C.; Martinez, I.; Johnston, M.R.; Brown, G.E., Jr. Morphological preservation of carbonaceous plant fossils in blueschist metamorphic rocks from New Zealand. Geobiology 2012, 10, 118-129.

26. Miot, J.; MacLellan, K.; Benzerara, K.; Boisset, N. Preservation of protein globules and peptidoglycan in the mineralized cell wall of nitrate-reducing, iron (II)-oxidizing bacteria: A cryo-electron microscopy study. Geobiology 2011, 9, 459-470.

27. Kremer, B.; Kazmierczak, J.; Lukomska-Kowalczyk, M.; Kempe, S. Calcification and silicification: Fossilization potential of cyanobacteria from stromatolites of Niuafo'ou's caldera lakes (Tonga) and implications for the early fossil record. Astrobiology 2012, 12, 535-548.

28. Li, J.; Benzerara, K.; Bernard, S.; Beyssac, O. The link between biomineralization and fossilization of bacteria: Insights from field and experimental studies. Chem. Geol. 2013, 359, 49-69.

29. Li, J.; Bernard, S.; Benzerara, K.; Beyssac, O.; Allard, T.; Cosmidis, J.; Mousou, J. Impact of biomineralization on the preservation of microorganisms during fossilization: An experimental perspective. Earth Planet. Sci. Lett. 2014, 400, 113-122.

30. Riding, R. Microbial carbonates: The geological record of calcified bacterial-algal mats and biofilms. Sedimentology 2000, 47, 179-214.

31. Burns, B.P.; Goh, F.; Allen, M.; Nellan, B.A. Microbial diversity of extant stromatolites in the hypersaline marine environment of Shark Bay, Australia. Environ. Microbiol. 2004, 6, 1096-1101.

32. Couradeau, E.; Benzerara, K.; Gérard, E.; Estève, I.; Moreira, D.; Tavera, R.; Lopez-Garcia, P. Cyanobacterial calcification in modern microbialites at the submicrometer scale. Biogeosciences 2013, 10, 5255-5266.

33. Dupraz, C.; Reid, R.P.; Braissant, O.; Decho, A.W.; Norman, R.S.; Visscher, P.T. Processes of carbonate precipitation in modern microbial mats. Earth Sci. Rev. 2009, 96, 141-162.

34. Charbonnier, S.; Vannier, J.; Hantzpergue, P.; Gaillard, C. Ecological significance of the arthropod fauna from the Jurassic (Callovian) La Voulte Lagerstätte. Acta Palaeontol. Pol. 2010, $55,111-132$.

35. Becker, K.; Wahl, M. Behaviour patterns as natural antifouling mechanisms of tropical marine crabs. J. Exp. Mar. Biol. Ecol. 1996, 203, 245-258. 
36. Goffredi, S.K.; Jones, W.J.; Erhlich, H.; Springer, A.; Vrijenhoek, R.C. Epibiotic bacteria associated with the recently discovered Yeti Crab, Kiwa hirsuta. Environ. Microbiol. 2008, 10, 2623-2634.

37. Tsuchida, S.; Suzuki, Y.; Fujiwara, Y.; Kawato, M.; Uematsu, K.; Yamanaka, T.; Yamamoto, H. Epibiotic association between filamentous bacteria and the vent-associated galatheid crab, Shinkaia crosnieri (Decapoda: Anomura). J. Mar. Biol. Assoc. UK 2010, 91, 23-32.

38. Fernandez-Leborans, G.; Tato-Porto, M.L. A review of the species of protozoan epibionts on crustaceans. I. Peritrich ciliates. Crustaceana 2013, 73, 643-683.

39. Wilby, P.R.; Briggs, D.E.G.; Riou, B. Mineralization of soft-bodied invertebrates in a Jurassic metalliferous deposit. Geology 1996, 24, 847-850.

40. Heaney, P.J.; Vicenzi, E.P.; Giannuzzi, L.A.; Livi, K.J.T. Focused ion beam milling: A method of site-specific sample extraction for microanalysis of Earth and planetary materials. Am. Mineral. 2001, 86, 1094-1099.

41. Langford, R.M. Focused ion beams techniques for nanomaterials characterization. Microsc. Res. Tech. 2006, 69, 538-549.

42. Drobne, D.; Milani, M.; Leser, V.; Tatti, F. Surface damage induced by FIB milling and imaging of biological samples is controllable. Microsc. Res. Tech. 2007, 70, 895-903.

43. Smith, A.J.; Munroe, P.R.; Tran, T.; Wainwright, M.S. FIB preparation of a sensitive porous catalyst for TEM elemental mapping at high magnifications. J. Mater. Sci. 2001, 36, 3519-3524.

44. Thompson, L.E.; Rice, P.M.; Delenia, E.; Lee, V.Y.; Brock, P.J.; Magbitang, T.P.; Dubois, G.; Volksen, W.; Miller, R.D.; Kim, H.-C. Imaging Thin Films of Nanoporous Low- $k$ Dielectrics: Comparison between Ultramicrotomy and Focused Ion Beam Preparations for Transmission Electron Microscopy. Microsc. Microanal. 2006, 12, 156-159.

45. Rubanov, S.; Munroe, P.R. FIB-induced damage in silicon. J. Microsc. 2004, 214, $213-221$.

46. Obst, M.; Gasser, P.; Mavrocordatos, D.; Dittrich, M. TEM-specimen preparation of cell/mineral interfaces by Focused Ion Beam milling. Am. Mineral. 2005, 90, 1270-1277.

47. Mayer, J.; Giannuzzi, L.A.; Kamino, T.; Michael, J. TEM sample preparation and FIB-induced damage. MRS Bull. 2007, 32, 400-407.

48. Bassim, N.D.; de Gregorio, B.T.; Kylcoyne, A.L.D.; Scott, K.; Chou, T.; Wirick, S.; Cody, G.D.; Stroud, R.M. Minimizing damage during FIB sample preparation of soft materials. J. Microsc. 2012, 245, 288-301.

49. Kilcoyne, A.L.D.; Tyliszczak, T.; Steele, W.F.; Fakra, S.; Hitchcock, P.; Franck, K.; Anderson, E.; Harteneck, B.; Rightor, E.G.; Mitchell, G.E.; Hitchcock, A.P.; Yang, L.; Warwick, T.; Ade, H. Interferometer-Controlled Scanning Transmission X-ray Microscopes at the Advanced Light Source. J. Synchrotron Radiat. 2003, 10, 125-136.

50. Ravel, B.; Newville, M. ATHENA, ARTEMIS, HEPHAESTUS: Data analysis for X-ray absorption spectroscopy using IFEFFIT. J. Synchrotron Radiat. 2005, 12, 537-541.

51. Rightor, E.G.; Hitchcock, A.P.; Ade, H.; Leapman, R.D.; Urquhart, S.G.; Smith, A.P.; Mitchell, G.; Fischer, D.; Shin, H.J.; Warwick, T. Spectromicroscopy of poly(ethylene terephthalate): Comparison of spectra and radiation damage rates in X-ray absorption and electron energy loss. J. Phys. Chem. B 1997, 101, 1950-1960. 
52. Braun, A.; Huggins, F.E.; Shah, N.; Chen, Y.; Wiric, S.; Mun, S.B.; Jacobsen, C.; Huffman, G.P. Advantages of soft X-ray absorption over TEM-EELS for solid carbon studies: A comparative study on diesel soot with EELS and NEXAFS. Carbon 2005, 43, 117-124.

53. Hitchcock, A.P.; Dynes, J.J.; Johansson, G.; Wang, J.; Botton, G. Comparison of NEXAFS microscopy and TEM-EELS for studies of soft matter. Micron 2008, 39, 311-319.

54. Braun, A.; Kubatova, A.; Wirick, S.; Mun, S. Radiation damage from EELS and NEXAFS in diesel soot and diesel soot extracts. J. Electron Spectrosc. 2009, 170, 42-48.

55. Wang, J.; Morin, C.; Li, L.; Hitchcock, A.; Scholl, A.; Doran, A. Radiation damage in soft X-ray microscopy. J. Electron Spectrosc. Relat. Phenom. 2009, 170, 25-36.

56. Ben-Jacob, E.; Schochet, O.; Tenenbaum, A.; Cohen, I.; Czirok, A.; Vicsek, T. Generic modelling of cooperative growth patterns in bacterial colonies. Nature 1994, 368, 46-49.

57. Lega, J.; Passot, T. Hydrodynamics of bacterial colonies. Nonlinearity 2007, 20, doi:10.1088/0951-7715/20/1/001.

58. Brandes, J.A.; Wirick, S.; Jacobsen, C. Carbon K-edge spectra of carbonate minerals. J. Synchrotron Rad. 2010, 17, 676-682.

59. Solomon, D.; Lehmann, J.; Kinyangi, J.; Liang, B.Q.; Heymann, K.; Dathe, L.; Hanley, K.; Wirick, S.; Jacobsen, C. Carbon (1s) NEXAFS Spectroscopy of Biogeochemically Relevant Reference Organic Compounds. Soil Sci. Soc. Am. J. 2009, 73, 1817-1830.

60. Benzerara, K.; Yoon, T.H.; Tyliszczak, T.; Constantz, B.; Sporman, A.M.; Brown, G.E. Scanning transmission X-ray microscopy study of microbial calcification. Geobiology 2004, 2, 249-259.

61. Benzerara, K.; Menguy, N.; Guyot, F.; Skouri, F.; de Luca, G.; Barakat, M.; Heulin, T. Biologically controlled precipitation of calcium phosphate by Ramlibacter tataouinesis. Earth Planet. Sci. Lett. 2004, 228, 439-449.

62. Benzerara, K.; Menguy, N.; Lopez-Garcia, P.; Yoon, T.H.; Kazmierczak, J.; Tyliszczak, T.; Guyot, F.; Brown, G.E., Jr. Nanoscale detection of organic signatures in carbonate microbialites. Proc. Natl. Acad. Sci. USA 2006, 103, 9440-9445.

63. Bontognali, T.R.R.; Vasconcelos, C.; Whartmann, R.J.; Dupraz, C.; Bernasconi, S.M.; McKenzie, J.A. Microbes produce nanobacteria-like structures, avoirding cell entombment. Geology 2008, 36, 663-666.

64. Spadafora, A.; Perri, E.; McKenzie, J.A.; Vasconcelos, C. Microbial biomineralization processes forming modern Ca:Mg carbonate stromatolites. Sedimentology 2010, 57, 27-40.

65. Rusznyak, A.; Akob, D.M.; Nletzsche, S.; Eusterhues, K.; Totsche, K.U.; Neu, T.R.; Frosch, T.; Popp, J.; Keiner, R.; Geletneky, J.; Katzschmann, L.; Schulze, E.D.; Kusel, K. Calcite biomineralization by bacterial isolates from the recently discovered pristine karstic Herrenberg cave. Appl. Environ. Microbiol. 2011, 78, 1157-1167.

66. Miot, J.; Benzerara, K.; Morin, G.; Kappler, A.; Bernard, S.; Obst, M.; Férard, C.; Skouri-Panet, F.; Guigner, J.M.; Posth, N.; Galvez, M.; Brown, G.E., Jr. Iron biomineralization by anaerobic neutrophilic iron-oxidizing bacteria. Geochim. Cosmochim. Acta 2009, 73, 696-711.

67. Leinweber, P.; Kruse, J.; Walley, F.L; Gillespie, A.; Eckhardt, K.U.; Blyth, R.I.; Regier, T. Nitrogen K-edge XANES-an overview of reference compounds used to identify unknown organic nitrogen in environmental samples. J. Synchrotron Radiat. 2007, 14, 500-511. 
68. Cody, G.; Alexander, C.; Yabuta, H.; Kilcoyne, A.A.; Ade, H.; Dera, P.; Fogel, M.; Militzer, B.; Myse, B. Organic thermometry for chondritic parent bodies. Earth Planet. Sci. Lett. 2008, 272, 446-455.

69. Nuevo, M.; Milam, S.; Sandford, S.; de Gregorio, B.; Cody, G.; Kilcoyne, A. XANES analysis of organic residues produced from the UV irradiation of astrophysical ice analogs. Adv. Space Res. 2011, 48, 1126-1135.

70. Stylo, M.; Alessi, D.S.; Shao, P.P.; Lezama-Pacheco, J.S.; Bergar, J.R.; Bernier-Latmani, R. Biogeochemical controls on the product of microbial U(VI) reduction. Envriron. Sci. Technol. 2013, 47, 12351-12358.

71. Vasconcelos, C.; McKenzie, J.A.; Bernasconi, S.; Grujic, D.; Tiens, A.J. Microbial mediation as a possible mechanism for natural dolomite formation at low temperatures. Nature 1995, 377, $220-222$.

72. Dupraz, S.; Parmentier, M.; Ménez, B.; Guyot, F. Experimental and numerical modeling of bacterially induced $\mathrm{pH}$ increase and calcite precipitation in saline aquifers. Chem. Geol. 2009, 265, 44-53.

73. Couradeau, E.; Benzerara, K.; Gerard, E.; Moreira, D.; Bernard, S.; Brown, G.E.; Lopez-Garcia, P. An early-branching microbialite cyanobacterium forms intracellular carbonates. Science $\mathbf{2 0 1 2}$, $336,459-462$.

74. Dupraz, C.; Fowler, A.; Tobias, C.; Visscher, P.T. Stromatolitic knobs in Storr's Lake (San Salvador, Bahamas): A model system for formation and alteration of laminae. Geobiology 2013, 11, 527-548.

75. Braissant, O.; Cailleau, G.; Dupraz, C.; Verrecchia, E.P. Bacterially induced mineralization of calcium carbonate in terrestrial environments: The role of exopolysaccharides and amino acids. J. Sediment. Res. 2003, 73, 485-490.

76. Van Lith, Y.; Warthmann, R.; Vasconcelos, C.; McKenzie, J.A. Microbial fossilization in carbonate sediments: A result of the bacterial surface involvement in dolomite precipitation. Sedimentology 2003, 50, 237-245.

77. Braissant, O.; Decho, A.W.; Dupraz, C.; Glunk, C.; Przekop, K.M.; Visscher, P.T. Exopolymeric substances of sulfate-reducing bacteria: Interactions with calcium at alkaline $\mathrm{pH}$ and implication for formation of carbonate minerals. Geobiology 2007, 5, 401-411.

78. Obst, M.; Dyes, J.J.; Lawrence, J.R.; Swerhone, G.D.W.; Benzerara, K.; Karunakaran, C.; Kaznatcheev, K.; Tyliszczak, T.; Hitchcock, A.P. Precipitation of amorphous $\mathrm{CaCO}_{3}$ (aragonite-like) by cyanobacteria: A STXM study of the influence of EPS on the nucleation process. Geochim. Cosmochim. Acta 2009, 73, 4180-4198.

79. Arp, G.; Reimer, A.; Reitner, J. Photosynthesis-induced biofilm calcification and calcium concentrations in phanerozoic oceans. Science 2001, 292, 1701-1704.

80. Vasconcelos, C.; Warthmann, R.; McKenzie, J.A.; Viwsscher, P.T.; Bittermann, A.G.; van Lith, Y. Lithifying microbial mats in Lagoa Vermelha, Brazil: Modern precambrian relics? Sediment. Geol. 2006, 185, 175-183.

81. Bosak, T.; Greene, S.E.; Newman, D.K. A likely role for anoxygenic photosynthetic microbes in the formation of ancient stromatolites. Geobiology 2007, 5, 119-126. 
82. Gallagher, K.L.; Kading, T.J.; Braissant, O.; Dupraz, C.; Visscher, P.T. Inside the alkalinity engine: The role of electron donors in the organoomineralization potential of sulfate-reducing bacteria. Geobiology 2012, 10, 518-530.

83. Benzerara, K.; Skouri-Panet, F.; Li, J.; Férard, C.; Gugger, M.; Laurent, T.; Couradeau, E.; Ragon, M.; Cosmidis, J.; Menguy, N.; Margaret-Olivier, I.; Tavera, R.; Lopez-Garcia, P.; Moreira, D. Intracellular Ca-carbonate biomineralisation is widespread in cyanobacteria. Proc. Natl. Acad. Sci. USA 2014, 111, 10933-10938.

84. Walsby, A.E.; Hayes, P.K.; Boje, R. The gas vesicles, buoyancy and vertical distribution of cyanobacteria in the Baltic Sea. Eur. J. Phycol. 1995, 30, 87-94.

85. Lawrence, J.R.; Swerhone, G.D.W.; Leppard, G.G.; Araki, T.; Zhang, X.; West, M.M.; Hitchcock, A.P. Scanning Transmission X-ray, laser scanning and transmission electron microscopy mapping of the exopolymeric patrix of microbial biofilms. Appl. Environ. Microbiol. 2003, 69, 5543-5554.

86. Cosmidis, J.; Benzerara, K.; Gheerbrant, E.; Esteve, I.; Bouya, B.; Amaghzaz, M. Nanometer-scale characterization of exceptionally preserved bacterial fossils in Paleocene phosphorites from Ouled-Abdoun (Morocco). Geobiology 2013, 11, 139-153.

87. Miot, J.; Recham, N.; Larcher, D.; Guyot, F.; Brest, J.; Tarascon, J.M. Biomineralized-Fe $\mathrm{O}_{3}$ : Texture and electrochemical reaction with Li. Energy Environ. Sci. 2014, 7, 451-460.

88. Lepot, K.; Benzerara, K.; Brown, G.E., Jr.; Philippot, P. Microbially influenced formation of 2,724-million-year-old stromatolites. Nat. Geosci. 2008, 1, 118-121.

(C) 2015 by the authors; licensee MDPI, Basel, Switzerland. This article is an open access article distributed under the terms and conditions of the Creative Commons Attribution license (http://creativecommons.org/licenses/by/4.0/). 